\title{
Interactive and Situated Learning in Education for Sustainability
}

\author{
Sergio Altomonte \\ Department of Architecture and Built Environment, The University of Nottingham, Nottingham, United \\ Kingdom, sergio.altomonte@nottingham.ac.uk
}

Brian Logan

School of Computer Science, The University of Nottingham, Nottingham, United Kingdom, brian.logan@nottingham.ac.uk

Markus Feisst

School of Computer Science, The University of Nottingham, Nottingham, United Kingdom, markus@feisst.net

Peter Rutherford

Department of Architecture and Built Environment, The University of Nottingham, Nottingham, United Kingdom, peter.rutherford@nottingham.ac.uk

Robin Wilson

Department of Architecture and Built Environment, University of Nottingham, Nottingham, United Kingdom, robin.wilson@nottingham.ac.uk

\section{Abstract}

Purpose: This study aimed to explore the opportunities offered by interactive and situated learning (elearning and m-learning) in support of education for sustainability in disciplines of the built environment. Design/methodology/approach: The paper illustrates the development of an online Portal and a mobile App aimed at promoting students' motivation and engagement with sustainability in design, and discusses the outcomes of their testing, investigating users' acceptance, comparing academic results, and analysing feedback. Findings: The findings add empirical evidence to the view that ICT-enhanced pedagogies can substantially contribute to the agenda of sustainability in higher education, primarily due to their affordance of interactive communication and contextualisation of knowledge, while guaranteeing flexible time and pace of learning. Research limitations/implications: The study solely focused on the development and testing of e-learning and m-learning tools to foster students' competence of sustainability in design studio work. The tools trialled were mostly at their prototypical stage and their testing included a relatively short-term evaluation and a narrow, self-selected, user base. However, the approach and findings are felt to be applicable to a much wider range of educational contexts. Originality/value: Interactive and situated pedagogical methods and tools have the potential to prompt a departure from transmissive educational models, encompassing at once theoretical, experiential, and analytic learning processes. This is of value to education for sustainability in disciplines of the built environment due to the requirement to holistically consolidate multi/inter/trans-disciplinary knowledge into a coherent design whole.

Keywords: Sustainability, Higher Education, E-Learning, M-Learning, Student-centred Learning, Deep Learning, Architecture, Built Environment 
Paper type: Research paper

Received: 03 January 2015; Revised: 28 February 2015, 06 June 2015; Accepted: 17 June 2015

Sergio Altomonte, Brian Logan, Markus Feisst, Peter Rutherford, Robin Wilson 2016. Interactive and situated learning in education for sustainability. International Journal of Sustainability in Higher Education, 17(3), pp.417 - 443

\section{Introduction}

The evidence of climate change, financial and socio-cultural concerns, market demands, and legislative requirements, are all pushing the agenda of sustainability to a central position in curricula of higher education. However, this is still confronted by multi-layered pedagogical challenges (Leal Filho, 2000). Educators need to tackle the complexities of learners' engagement, negotiating with its several dimensions, and motivating students to apply knowledge of sustainability in their work. Logistical factors and attitudinal approaches also impact upon effective education for, and of, sustainability. Academics and students often struggle to depart from purely transmissive pedagogical models, where knowledge is delivered independently from its practical exploration (Altomonte et al., 2014).

In disciplines of the built environment, an international enquiry reveals that academic programs are often split in theoretical and applied teaching streams (EDUCATE, 2012a). Technical knowledge is delivered in ex-cathedra lectures, while the design studio serves as the forum for synthesizing into creative projects the principles acquired in satellite disciplinary domains. At the lectures, students attain the core knowledge that then, in the studio, should inform the design. Frequently, however, lectures are fragmented and detached from synthetic coursework, hindering students from engaging with an integrated pedagogical process (Wright, 2003; lulo et al., 2013). Although allegedly delivering the targeted learning outcomes, this naïve conception of knowledge acquisition and application deters the transfer of technical competence into inspired design (Gelernter, 1988). Conversely, deep learning - and the incentive to search for underlying meanings (Marton and Säljö, 1976) - should be enhanced through anchoring principles and values with experience, and establishing an effective dialogue across disciplines based on active engagement to the learning process. This is central to education for sustainability in design due to its inherent multi/inter/trans-disciplinary nature, and the necessity to critically and holistically organize disparate knowledge into a coherent whole (Warburton, 2003).

To tackle such frailties and promote a comprehensive theoretical (conceptual acquisition), experiential (practical application), and analytic (reflective evaluation) education - while making knowledge-sharing platforms "more accessible for different kinds of audiences" (Leal Filho et al., 2015) - substantive contribution can be offered by Information and Communication Technologies (ICTs) and e-learning, an umbrella term here used to capture tools such as open-source educational systems, massive online open courses, virtual learning environments, etc. (Moore et al., 2011).

Most higher education institutions nowadays integrate e-learning, at least to some extent, within their pedagogical provisions to enhance teaching, learning, and assessment, and to improve students' satisfaction and outcomes (Gikas and Grant, 2013). E-learning is also offering a response to some of 
the challenges that universities are facing, such as the need to widen their geographical boundaries, support distance-based learning, react to pressures on space and staff time, to a more varied student body, and to the demand for more integrated teamwork and collaboration between disciplines.

Several studies have analysed the impact of ICTs on higher education. Students of today, in fact, have grown up with internet and computers, these having likely impacted on their cognitive styles (Thompson, 2013; Herrington and Oliver, 2000). From a learning perspective, the digital natives (Prensky, 2001) - also defined as gamer (Beck and Wade, 2006) or net generation (Tapscott, 1998) have been deemed to possess a preference for speed, nonlinear processing, multitasking, and social learning, allegedly developed through immersion in digital technologies during childhood and adolescence (Bekebrede et al., 2011). Evidently, these learning preferences require adequate ways of education, based on flexibility of format and ease of access to knowledge, so as to create engagement with the learning process (Furió et al., 2013), enhance motivation and satisfaction (Littlejohn et al., 2008), accommodate multiple learning styles (Kolb, 1984), provide a context for interaction and decision making (Kebritchi and Hirumi, 2008), and situate the education on-the-move (Traxler, 2010). As with the people-centric Web 2.0, the emphasis of pedagogical processes is shifting towards content creation rather than consumption, and on cooperation rather than regulation (Brown, 2014).

Based on the analysis of the literature and as part of the European project EDUCATE (Environmental Design in University Curricula and Architectural Training in Europe), this study aimed to explore the opportunities offered by interactive and mobile learning in curricula of architecture and related disciplines of the built environment to stimulate participative and reflective learning, enhance situated exploration of knowledge, and encourage reflection on the scope, boundaries, and complementary nature of subject-specific domains, all core elements to an integrated design education informed by the agenda of sustainability. The purpose of this paper is to illustrate the development of an e-learning platform (EDUCATE Portal) and a mobile App (EDUCATE on SITE) and examine the results of their testing, analysing users' acceptance of the services, comparing the academic results obtained by students, and appraising the feedback received. Finally, the paper critically discusses the affordances of interactive and situated learning in support of deep and studentcentred education for sustainability in the design of the built environment.

\section{The EDUCATE Portal}

The project EDUCATE (www.educate-sustainability.eu) was set up to promote education for sustainability in curricula of the built environment, involving seven academic partners supported by professional bodies, building practitioners, and experts of education and ICTs. Its objectives were to:

- Analyse pedagogical barriers to the integration of sustainability within creative design;

- Define and test a framework for curriculum development informed by sustainability;

- Propose the harmonisation of higher education and qualification requirements;

- Disseminate know-how to students, educators, professionals, and the public.

In support of these objectives, an interactive e-learning platform - the EDUCATE Portal - was developed to foster the synchronous and asynchronous exchange of knowledge across user groups, reinforcing a holistic approach to education where analytic skills, cross-referencing, and critical 
thinking facilitate a critical conversation across disciplines. The Portal was designed to provide for a range of functionalities, among which hosting a wide knowledge base on sustainability in design, a discussion forum, subject-specific reading lists, the possibility of asking questions to instructors, consulting frequently asked questions, and enhancing tutor-to-peer and peer-to-peer feedback. The design of the Portal was based on the open-source content management system (CMS) Drupal, consisting of a core system that can be extended by plug-ins. However, since no plug-in (or combination thereof) could support all the functionalities required, the development of new bespoke software was necessary. Given the novelty of the Portal, and the difficult predictability of how the platform would be employed, its configuration incorporated major flexibility to adapt to end-users' expectations. Its structure consisted of four domains: Student Space; Instructor Space; Professional Space; and, Public Space. These domains interacted in a Forum centred on a Knowledge Base.

The Knowledge Base represented the collected expertise of the EDUCATE partners in key concepts of sustainability, structured in three main Parts (Table 1). Indeed, the literature (e.g., Jones et al., 2010) suggests that a theoretical background is essential to provide users with the ability of translating physical laws in creative design (Issues and Principles). This, however, has to be supported by experiential evidence-based knowledge - for principles to be applied in practice (Applications and Case Studies) - and by analytical instruments - that can facilitate the testing and comparison of hypotheses, and make performance predictions from early design stages (Tools). Each Part was organised in an ontology - subdivided in Categories and Clusters - forming an element of content retrieval. Each Cluster grouped a related set of topics, case studies, and analytical resources. The content was presented in five Tabs, different for each Part, offering complementary levels of analysis.

Table 1. Structure of the EDUCATE Knowledge Base (available on www.educate-sustainability.eu/kb)

\begin{tabular}{|c|c|c|c|}
\hline Parts & Categories & Clusters & Tabs \\
\hline \multirow{6}{*}{$\begin{array}{l}\text { Issues and } \\
\text { Principles } \\
\text { (Theoretical) }\end{array}$} & $\begin{array}{l}\text { The Environmental } \\
\text { Challenge }\end{array}$ & $\begin{array}{l}\text { Climate Change } \\
\text { Environmental Policies }\end{array}$ & \multirow{6}{*}{$\begin{array}{l}\text { Principles } \\
\text { In Depth } \\
\text { Applications } \\
\text { Teaching Resources } \\
\text { Learning Resources }\end{array}$} \\
\hline & Climate and Comfort & $\begin{array}{l}\text { Climate and Weather } \\
\text { Thermal Comfort } \\
\text { Visual Comfort } \\
\text { Indoor Air Quality } \\
\text { Building Typology } \\
\text { Outdoor Spaces }\end{array}$ & \\
\hline & Heating and Cooling & $\begin{array}{l}\text { Thermal Environment } \\
\text { Psychrometry } \\
\text { Thermal Behaviour of Buildings } \\
\text { Steady-state Heat Flow } \\
\text { Dynamic Response of Buildings } \\
\text { Moisture Control } \\
\text { Passive Design Principles } \\
\text { Control Potential Zones } \\
\text { Passive Design Systems } \\
\text { Active Design Systems }\end{array}$ & \\
\hline & Ventilation & Natural Ventilation & \\
\hline & Lighting & $\begin{array}{l}\text { Physics of Light } \\
\text { Natural Lighting } \\
\text { Artificial Lighting }\end{array}$ & \\
\hline & Acoustics & $\begin{array}{l}\text { Acoustics in Design } \\
\text { Materials in Acoustics } \\
\text { The Reverberation Process }\end{array}$ & \\
\hline
\end{tabular}




\begin{tabular}{|c|c|c|c|}
\hline & $\begin{array}{l}\text { Urban Quality } \\
\text { Ecological Footprint } \\
\text { Resources and Waste } \\
\text { Management } \\
\text { Buildings and Cities }\end{array}$ & $\begin{array}{l}\text { Sound Insulation } \\
\text { Eco-masterplanning } \\
\text { Environment, society and economy } \\
\text { Environmental Impacts } \\
\text { Production Cycles } \\
\text { Water Management } \\
\text { Waste Management } \\
\text { Renewable Energy Sources } \\
\text { History and Theory } \\
\text { Use of Energy }\end{array}$ & \\
\hline $\begin{array}{l}\text { Applications } \\
\text { and Case Studies } \\
\text { (Experiential) }\end{array}$ & $\begin{array}{l}\text { Culture } \\
\text { Education } \\
\text { Urban Development } \\
\text { Residential and Mixed Use } \\
\text { Workplaces } \\
\text { Sport and Leisure } \\
\end{array}$ & $\begin{array}{l}\text { Field Studies } \\
\text { Design Projects }\end{array}$ & $\begin{array}{l}\text { Project } \\
\text { Layout } \\
\text { Construction } \\
\text { Observations } \\
\text { Performance }\end{array}$ \\
\hline $\begin{array}{l}\text { Tools } \\
\text { (Analytical) }\end{array}$ & $\begin{array}{l}\text { Daylighting } \\
\text { Space Heating \& Cooling } \\
\text { Thermal Comfort } \\
\text { Onsite Measurements } \\
\text { Climate Data } \\
\text { Solar Access and Control }\end{array}$ & $\begin{array}{l}\text { Design, Research and Performance } \\
\text { Studies }^{\text {a }}\end{array}$ & $\begin{array}{l}\text { Task } \\
\text { Tools } \\
\text { Utilisation } \\
\text { Applications } \\
\text { Resources }\end{array}$ \\
\hline
\end{tabular}

a In Applications and Case Studies and in Tools, the Clusters were common to all Categories of contents

The Forum was designed to support two functionalities: Discussion and Frequently Asked Questions (FAQs). The Discussion supported dialogue between users, so that comments, information, data, links, etc. could be shared. The FAQs responded to the most common enquiries on topics, case studies, and tools. The questions and answers were grouped with the same ontology of the Knowledge Base, for them to be browsed per category of interest. Discussions and FAQs could be tailored to address the needs of specific user groups and, eventually, be made publicly available.

The Student Space was developed to provide several functionalities:

- Search the Knowledge Base. Students at participating institutions were given access to the Knowledge Base to look for contents via a conventional search function based on keywords or performing an advanced search according to Part, Category, and/or Cluster.

- Access Reading Lists. To help students find information, an instructor at a partner institution could generate a Reading List consisting of an ordered, annotated set of links to the Knowledge Base relevant to a module. Each student was able to access all the Reading Lists set up by each of the project partners, so as to foster exchange of methods and contents.

- Ask a question. If students were unable to find a solution to a problem, they were given the possibility to ask a question online to an instructor. The question and the answer could be made visible to other users at the discretion of the instructor, who could decide to transfer them to the FAQs based on their relevance. To allow enquiries to be directed to instructors according to their expertise, each question had to be tagged with Categories and/or Clusters from the Knowledge Base, to be chosen from a drop-down menu. Questions could be accompanied by a file to contextualise the problem.

- Upload work and comment on another student's work. Students could upload their work on the Student Space to receive feedback by instructors and peers, or for assessment. To facilitate these 
functionalities, students could organise their work in five folders: Private; Request for feedback; Group; Submission; and, Gallery. Formative and summative feedback was given in a text field that allowed the reviewer to insert links and/or images. If the student revised their work based on the comments received and wished to obtain further feedback, they could make a new enquiry. In this case, the student had to indicate the relationship to the previous request and to the comments addressed so as to break the progression of the work into snapshots, with their associated feedback.

The Instructor Space was designed to allow tutors at partner institutions to set up Reading Lists, arrange a discussion area, visualise the progress of their students, provide answers to questions, populate the FAQs, offer feedback to interim and final submission, and evaluate peer-reviewing.

The Professional Space was designed to provide practitioners affiliated with a professional body involved in EDUCATE with access to the Knowledge Base and to Reading Lists specifically set up for continuing professional development. Practitioners could also browse the FAQs, post questions to instructors, and participate to a discussion forum held in national language.

The Public Space was accessible from the EDUCATE website, and included a non-editable version of the Knowledge Base, project outputs, newsletters, a survey on the challenges and opportunities of sustainability in design, and external links.

Further details on the structure and stages of implementation of the EDUCATE Portal, including screenshots of its functionalities, are available in (EDUCATE, 2012b).

\section{EDUCATE on SITE}

The EDUCATE Portal was originally intended to support pedagogical practices in the design studio. However, initial feedback highlighted that increasingly more users utilize mobile devices to search for information and interact with others on-the-move. Hence, a spin-off project - EDUCATE on SITE (SITuated Education) - was set up to analyse user acceptance of a mobile service for the Portal and study if it could afford situated learning, combining theoretical education with experience in-situ.

To select the best approach to optimise access to the Portal from a mobile phone or tablet, constraints of the device and of the CMS were weighed up. Besides connectivity, some of the limitations of mobile devices are their screen size and resolution. Although web content can be optimised for a mobile browser, screen space may be wasted due to navigation elements that are difficult to hide. Another problem with most CMSs is that images are not optimised for mobile browsing. A standard way to adapt images for mobiles' screens is to adjust them via client side scaling (CSS); however, transferring high resolution images requires more bandwidth and can increase connection costs. Also, not all plug-ins are supported on a mobile device, file upload is not available on all operating systems, and the mobile browser may not offer a reliable offline mode (it may or not cache files). Moreover, constraints with the central processing unit and memory should be considered, as well as the available storage. These problems can be solved by an application (App) that can be optimised to the screen size and allow an offline mode. However, different Apps are needed for each operating system (e.g., iOS, Android, Windows Mobile, Symbian), with an interface that might be different to the web version (Altomonte et al., 2012). 
In the case of the EDUCATE Portal, considering the advantage to generate and maintain local cached data, it was decided to design an App, together with optimising access from the device browser. For this proof-of-concept prototype, the need to develop different Apps for each mobile system was not deemed essential, and thus the App was created solely for Android devices. Feedback from users suggested the functionalities to be made available: accessing the Knowledge Base, asking a question, and the consultation of FAQs. The Forum was seen as less relevant (perhaps due to more typing involved), although the demand was sufficient to also consider incorporating this function. In addition, the design of a new location-based service was also included. This would show the user's position on a Google map and identify nearby case studies featured in the Knowledge Base. Clicking on any of these would provide the visualisation of some basic data and a link to the full information available in the Applications and Case Studies. Further details on the design and implementation of the EDUCATE on SITE App are provided in (Altomonte et al., 2012).

\section{Methods}

Testing of the EDUCATE Portal

Throughout the EDUCATE project, the Portal was made accessible to staff and students at partner organisations. Concurrently, selected practitioners explored the use of the Portal in support of continuing professional development. Different user groups were provided with account types tailored to their educational needs. The Portal was tested in two stages during the academic years 2010/11 (Pilot Study) and 2011/12 (Field Test). The initial pilot aimed to measure the ease of use and pedagogic integration of the Portal, appraise feedback, evaluate learning outcomes, and address features that required further development. The second stage of testing also included an international award open to external students and their tutors. The number of users involved in the testing is considered adequate to allow an objective evaluation of the results. During the pilot, 1,130 users, including academics, students, and professionals, were given an account on the Portal. In the second stage of analysis, further 456 users were registered at partner organisations, and 387 external accounts (staff and students) - in representation of 64 Universities from 25 countries - were created in the context of the student award. This brought the number of users involved in the testing to 1,973.

To provide an assessment of the efficacy of the Portal in supporting education for sustainability, various indicators have been considered: analysis and comparison of students' results; appraisal of feedback from students; and, collection of responses to a survey.

Among others, the testing involved a first year module offered at a UK University. The module introduced the sustainability agenda as it applies to the built environment, and explored quantitatively and qualitatively the environmental strategies applied in architectural design projects. The module was assessed by coursework completed alongside the delivery of theoretical contents. In the analysis of results, final marks obtained by students in the academic year 2009/10 (i.e., the onset of EDUCATE) were taken as a baseline for comparison. Following the launch of the Portal in 2010/11, students received an account to access the Knowledge Base and post comments on a discussion forum moderated by the module convenor. In 2011/12, students were provided with further interactive 
functionalities: a Reading List highlighting the topics of the Knowledge Base relevant to the module; a student-managed discussion area to foster peer-learning; and, the possibility to ask questions online.

In terms of user feedback, students' evaluations of the module were collected to gather views on its pedagogical provisions and the challenges and opportunities of online learning, and to obtain openended comments on how to improve the teaching and promote the learning experience.

Finally, to ascertain end-user acceptance of the Portal, a survey was administered to all its users at the end of each stage of testing. The survey presented respondents with several statements, using a 5-point ordered Likert scale ranging from 'strongly agree' (+2) to 'strongly disagree' (-2).

\section{Evaluation of the EDUCATE on SITE App}

Following the development of the EDUCATE on SITE App, an evaluation (Trial Run) was set up to analyse its usability compared to accessing the Portal from a mobile device browser. The study also aimed to examine the degree to which the greater flexibility in the use of screen space and interaction allowed by an App could offset its lack of familiarity and the need to learn a new interface. The Trial Run focused specifically on the features related to browsing the Knowledge Base and asking a question. Other functionalities (Map, Forum, and FAQs) were disabled in this study.

Eleven students, six undergraduates and five postgraduates, volunteered to participate to the evaluation. Purposeful sampling was used to recruit the test subjects via an advertisement posted through the students' society. The Trial Run was carried out at a UK University campus that incorporates many features of sustainable design, thus forming an ideal setting for the study. Volunteers were asked to utilize mobile devices to retrieve information on the buildings on campus from the EDUCATE Portal, both via its web-based version and the EDUCATE on SITE App. Students were given the option to use their own smartphone or tablet, or to borrow one from the organisers with the EDUCATE on SITE App pre-installed. All volunteers were given a practical demonstration on how to access the Portal via the mobile browser and the App, also to allow participants using a lent device to familiarise with its operation. The students were divided in four groups: three with three members, and one with two members. Each group included at least one student equipped with an Android mobile device, so that all students could trial the EDUCATE on SITE App, even if accessing the online version of the Portal. To ensure that all participants engaged with the evaluation, each group was assigned a location on campus and received a task to fulfil by consulting the Knowledge Base from their mobile device. In addition, students were asked to post questions on the Portal related to their task, which were answered in real-time by an Instructor. At the end of the tasks, a survey on mobile access to the Portal was administered to participants (Post-questionnaire), featuring statements presented on a 5-point ordered Likert scale from 'strongly agree' (+2) to 'strongly disagree' (-2).

\section{Statistical Analysis}

Different methods have been utilised to measure the indicators considered.

The academic results attained by students were analysed using as benchmark the distribution of marks in the year before the implementation of the EDUCATE Portal (2009/10). These were compared with the two stages of testing by calculating, for each, descriptive statistics (mean, standard deviation, 
and standard error) and testing the statistical significance and practical relevance of differences. All other variables that could account for changes in academic results have been regarded as controlled and thus masked from the statistical analysis. In fact, the lecturer of the module, the material taught, students' admission requirements, the size of the student group, the briefs for the assignments, and the assessment criteria, were all maintained identical during the three years of testing. The ShapiroWilk test was used to verify whether data were normally distributed. The Kolmogorov-Smirnov (K-S) test quantified the distance between the samples' empirical distribution functions.

To test the hypothesis that the distributions of marks have changed across the three years of testing, a non-parametric Kruskal-Wallis one-way analysis of variance (ANOVA) was used (data were independent and errors were non-normally distributed), followed by post-hoc one-sided MannWhitney-Wilcoxon tests between each sample. Since several tests were performed on the same data, to avoid inflating the overall Type I error, a Bonferroni correction was applied dividing the accepted probability (0.05) by the number of tests (3) (Field and Hole, 2003). Hence, the tests were considered significant when $p<0.016$ (i.e., $0.05 / 3$ ). To quantify the relevance of statistically significant differences, the effect size index was calculated for each influence tested (Cohen, 1994; Schiavon and Altomonte, 2014). There are indeed limitations with using null hypothesis significance testing as a way of inferring the size (or relative impact) of the differences between samples. The main one is that the $p$-value depends on the sizes of both the effect and the sample. Conversely, by placing the emphasis on the standardized mean difference between sample groups, and not just on its statistical significance, the effect size shows if the predictor variable has any practical relevance (Ellis, 2010). Due to the ordinal nature of the data, the effect size was calculated as a group difference index, i.e. the difference between two group outcomes divided by the pooled samples' standard deviation (Kulik and Kulik, 1991). The interpretation of the results (d-index) derived from (Cohen, 1992), where benchmarks have been proposed for 'small', 'medium', and 'large' effect sizes ( $d \geq 0.20,0.50$, and 0.80 , respectively).

To analyse the distribution of responses to the EDUCATE Portal survey, descriptive statistics were calculated, differences in tendencies between the two stages of testing (Field Test vs. Pilot Study) were measured, and statistical significance and practical relevance of differences were tested using the Mann-Whitney-Wilcoxon test and the d-index effect size. The tests were considered statistically significant when $p<0.05$. Correlation techniques were used to analyse the strength of association between responses, using the non-parametric Spearman rho $(\rho)$ coefficient due to the ordinal character of the variables and their non-normal distribution. Based on (Ferguson, 2009), the correlation was considered 'small', 'moderate', and 'strong' for, respectively, $\rho \geq 0.20,0.50$ and 0.80 .

Finally, the analysis of the outcomes of the EDUCATE on SITE Post-questionnaire was mainly based on descriptive statistics and qualitative appraisal of feedback, due to a very small sample size. Statistical significance and effect size of differences between responses were also explored using a Mann-Whitney-Wilcoxon test and the d-index. All analyses were carried out with R software 2.15.1. 


\section{Results}

\section{Academic Results and Students' Feedback}

Table 2 presents descriptive statistics of students' final marks in 2010/11 and 2011/12 compared to the baseline represented by the results prior to the implementation of the EDUCATE Portal $(2009 / 10)$. The data indicate that the mean mark $(\mu)$ increased from 55.03 in $2009 / 10$ to 57.00 in 2010/11 and to 59.26 in 2011/12. Medians followed a similar trend. Increases in skewness (from -0.34 to -0.87 ) and kurtosis (from 0.06 to 1.99 ) signal that marks have progressively deviated from a normal distribution with a density peaking towards higher values. In fact, the Shapiro-Wilk test indicates a normal distribution for 2009/10 ( $p>0.05)$, while distributions are non-normal and negatively skewed for 2010/11 and 2011/12 ( $p<0.001)$.

Table 2. Descriptive statistics of students' final marks

\begin{tabular}{l|c|c|c|c|c|c|c}
\hline Academic Year & $\mathbf{N}^{\mathbf{a}}$ & Mean $(\boldsymbol{\mu})$ & Median & SD $^{\mathbf{a}}$ & SE $^{\mathbf{a}}$ & Skewness $^{\text {Kurtosis }}$ \\
\hline Academic year 2009/10 & 205 & 55.03 & 56.00 & 8.31 & 0.58 & -0.34 & 0.06 \\
Academic year 2010/11 & 190 & 57.00 & 58.00 & 6.66 & 0.48 & -0.82 & 1.53 \\
Academic year 2011/12 & 170 & 59.26 & 60.00 & 7.28 & 0.56 & -0.87 & 1.99 \\
\hline
\end{tabular}

${ }^{a} \mathrm{~N}=$ number of students; $\mathrm{SD}=$ standard deviation; $\mathrm{SE}=$ standard error

Figure 1 provides a boxplot of the distribution of marks across the three academic years.

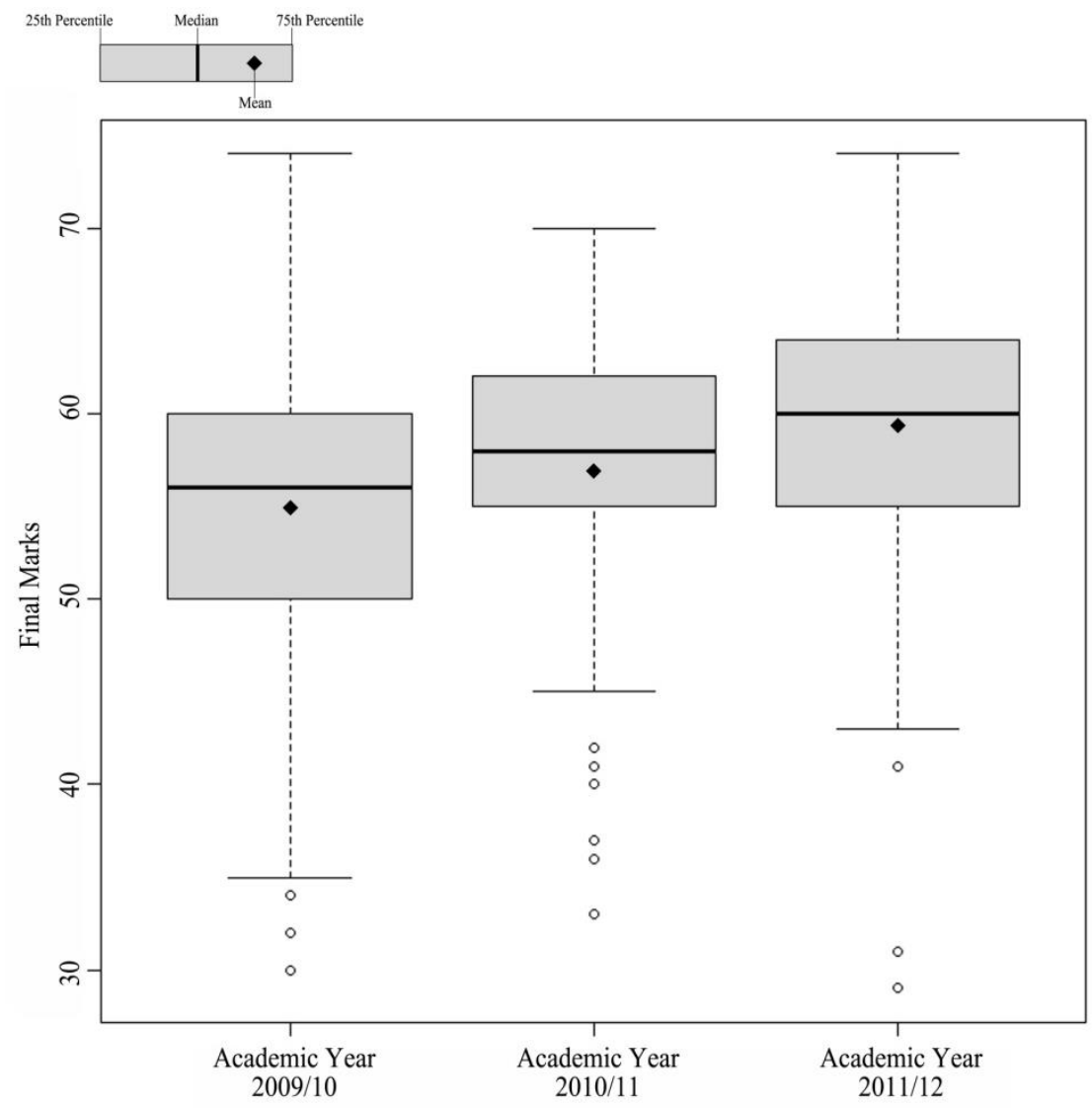

Figure 1. Boxplots of students' final marks throughout the testing of the EDUCATE Portal 
Table 3 presents the differences of the means $(\Delta \mu)$, the distance between the empirical distribution functions ( $p$-value, two-sided K-S test), the statistical significance of the differences ( $p$-value, one-sided Mann-Whitney-Wilcoxon test), and the effect size (d-index) for the three comparisons. The Kruskal-Wallis ANOVA indicates a variation between the final marks across the three years of testing, $H(2)=30.22, p<0.001$. Subsequent pairwise comparisons of the mean ranks between samples confirms that marks have progressively increased from 2009/10 to 2011/12, and that their differences are statistically significant ( $p<0.016$, with Bonferroni correction). The effect size of the variations is practically relevant for the differences in mean marks between 2009/10 and 2010/11 ( $d=0.26$ ), and 2010/11 and 2011/12 ( $d=0.32)$. A higher and substantive effect size ( $d=0.54)$ is detected for the increase in marks between the academic year 2009/10 and the second year of testing, 2011/12.

Table 3. Differences of the means $(\Delta \mu)$, distance between the empirical distribution functions (K-S), statistical significance of the differences (Mann-Whitney-Wilcoxon), and effect size

\begin{tabular}{l|c|c|c|c}
\hline Two-samples tests & $\Delta \mu$ & $\begin{array}{c}\text { Komolgorov-Smirnov } \\
p \text {-value, two-sided }\end{array}$ & $\begin{array}{c}\text { Mann-Whitney-Wilcoxon } \\
p \text {-value, one-sided }\end{array}$ & $\begin{array}{c}\text { Effect size } \\
\text { d-index }^{\mathrm{b}}\end{array}$ \\
\hline $2010 / 11$ vs. $2009 / 10$ & +1.97 & $0.0004^{* *}$ & $0.00034^{* *}$ & 0.26 \\
$2011 / 12$ vs. $2010 / 11$ & +2.26 & $0.0159^{*}$ & $0.00521^{*}$ & 0.32 \\
$2012 / 11$ vs. $2009 / 10$ & +4.23 & $<0.0003^{* *}$ & $<0.0003^{* *}$ & 0.54 \\
\hline
\end{tabular}

${ }^{a}$ (with Bonferroni correction) ${ }^{* * *} p<0.0003 ;{ }^{* *} p<0.003 ;{ }^{*} p<0.016$; ns= not significant

${ }^{b} d \geq 0.20=$ small; $d \geq 0.50=$ medium; $d \geq 0.80=$ large (all reported effect sizes are significant at the .05 level)

Table 4 gives a summary of the feedback provided by students at the end of the first year of testing (2010/11), in terms of the implementation of the EDUCATE Portal.

Table 4. Selected feedback obtained in students' evaluations

\footnotetext{
Weaknesses and Threats

The layout of the EDUCATE Portal can be complex for users not proficient in environmental science theory

There is a strong competition from other internet-based resources (e.g., Google search)

The EDUCATE Portal is not yet largely diffused, thus limiting opportunities for online discussion

The EDUCATE Portal can boost professional competence, but it cannot be a total substitute to one-to-one tuition

For assessment, printed drawings and physical models cannot be completely replaced by online submissions

E-learning needs to be coupled with lectures, self-study, face-to-face tutoring, seminars and workshops

If some of the Tools could be used directly on the Portal, its practical benefits would increase

Students and staff need time to acquire familiarity with electronic media for a confident application in education

For the Portal to be accessed from mobile devices, it would require optimisation of its contents and functionalities

Strengths and Opportunities

The EDUCATE Portal provides an opportunity to contextualise and consolidate knowledge at the user's pace The Portal enables the sharing of knowledge, peer-learning, online tutoring, and cooperation in design research The Portal can reduce the need for unnecessary printing, allowing to get instant feedback off tutors and peers The Knowledge Base is a valid navigation through the theoretical, empiric, and analytic domains of sustainability The delivery of knowledge in layers of increasing detail (Tabs) makes the Knowledge Base most useful The varied use of media in the Knowledge Base makes the learning experience more engaging Reading Lists are an interesting way to direct the learning of specific groups of users The Discussion Forum can be an useful tool for networking with other users It would be useful to include in the Portal an online streaming of tutorials or lectures
} 


\section{EDUCATE Portal Survey}

Out of the 1,973 direct users of the EDUCATE Portal, 405 responded to the online survey $(21 \%$ of the population). Specifically, 312 users (out of 1,$130 ; 28 \%$ ) answered the survey at the end of the first stage of testing (Pilot Study) and 93 (out of $843 ; 11 \%$ ) responded at the conclusion of the second phase of study (Field Test), after several new interactive features had been implemented. Table 5 provides a summary of the results under selected statements of the survey. The table reports descriptive statistics (mean, standard deviation, and standard error) of users' votes, separately considering the responses of all users and each of the two stages of testing. Table 5 also provides an analysis of the variations in users' votes tendencies $(\Delta \mu)$ between the Field Test and the Pilot Study, the statistical significance of the differences ( $p$-value), and their effect size (d-index).

Table 5. Descriptive statistics, null hypothesis significance testing (NHST, one-sided), and effect size for selected statements of the EDUCATE Portal Survey

\begin{tabular}{|c|c|c|c|c|c|c|c|c|c|c|c|c|}
\hline \multirow[t]{2}{*}{ Proposed Statement } & \multicolumn{3}{|c|}{$\begin{array}{c}\text { All Users } \\
(\mathrm{N}=405)\end{array}$} & \multicolumn{3}{|c|}{$\begin{array}{l}\text { Pilot Study } \\
(\mathrm{N}=312)\end{array}$} & \multicolumn{3}{|c|}{$\begin{array}{l}\text { Field Test } \\
(\mathrm{N}=93)\end{array}$} & \multicolumn{2}{|c|}{$\begin{array}{c}\text { NHST } \\
\text { (Field vs. Pilot) }\end{array}$} & \multirow{2}{*}{$\begin{array}{c}\text { Effect } \\
\text { Size } \\
d^{c}\end{array}$} \\
\hline & $\mu^{\mathrm{a}}$ & $S D^{a}$ & $\mathrm{SE}^{\mathrm{a}}$ & $\mu^{\mathrm{a}}$ & $S D^{a}$ & $S E^{a}$ & $\mu^{\mathrm{a}}$ & $S D^{a}$ & $\mathrm{SE}^{\mathrm{a}}$ & $\Delta \mu$ & $p^{b}$ & \\
\hline \multicolumn{13}{|c|}{ A. The use of e-learning tools in education } \\
\hline $\begin{array}{l}\text { E-learning can support } \\
\text { education for sustainability in } \\
\text { design }\end{array}$ & 1.07 & 0.90 & 0.04 & 1.02 & 0.94 & 0.05 & 1.25 & 0.69 & 0.07 & 0.23 & $0.040^{*}$ & 0.26 \\
\hline $\begin{array}{l}\text { E-learning can support time } \\
\text { management and autonomy in } \\
\text { learning }\end{array}$ & 0.88 & 1.00 & 0.05 & 0.81 & 1.05 & 0.06 & 1.10 & 0.75 & 0.08 & 0.29 & $0.026^{*}$ & 0.29 \\
\hline $\begin{array}{l}\text { E-learning can encourage users } \\
\text { to take responsibility of their own } \\
\text { learning }\end{array}$ & 0.69 & 1.13 & 0.06 & 0.64 & 1.17 & 0.07 & 0.83 & 0.98 & 0.10 & 0.19 & $0.165 \mathrm{~ns}$ & 0.17 \\
\hline $\begin{array}{l}\text { Online interactions among users } \\
\text { enhance motivation and } \\
\text { engagement }\end{array}$ & 0.94 & 1.00 & 0.05 & 0.89 & 1.04 & 0.06 & 1.11 & 0.81 & 0.08 & 0.23 & $0.062 \mathrm{~ns}$ & 0.23 \\
\hline \multicolumn{13}{|l|}{$B$. The use of the EDUCATE Portal } \\
\hline $\begin{array}{l}\text { The layout, structure and } \\
\text { navigation of the EDUCATE } \\
\text { Portal are intuitive }\end{array}$ & 0.38 & 1.20 & 0.06 & 0.29 & 1.24 & 0.07 & 0.72 & 0.98 & 0.10 & 0.43 & $0.003^{\star *}$ & 0.36 \\
\hline $\begin{array}{l}\text { The EDUCATE Portal has } \\
\text { supported my interest in } \\
\text { sustainable design }\end{array}$ & 0.69 & 1.07 & 0.05 & 0.60 & 1.12 & 0.06 & 1.00 & 0.80 & 0.08 & 0.40 & $0.005^{\star *}$ & 0.37 \\
\hline $\begin{array}{l}\text { The EDUCATE Portal has } \\
\text { helped my teaching and learning } \\
\text { experience }\end{array}$ & 0.54 & 1.08 & 0.05 & 0.49 & 1.12 & 0.06 & 0.74 & 0.91 & 0.09 & 0.24 & $0.080 \mathrm{~ns}$ & 0.23 \\
\hline $\begin{array}{l}\text { I intend to use the EDUCATE } \\
\text { Portal in my future teaching and } \\
\text { learning }\end{array}$ & 0.94 & 1.01 & 0.05 & 0.85 & 1.09 & 0.06 & 1.26 & 0.58 & 0.06 & 0.41 & $0.005^{\star *}$ & 0.41 \\
\hline \multicolumn{13}{|l|}{ C. The EDUCATE Knowledge Base } \\
\hline $\begin{array}{l}\text { The contents of the EDUCATE } \\
\text { Knowledge Base are relevant } \\
\text { and useful }\end{array}$ & 0.87 & 0.94 & 0.05 & 0.81 & 1.01 & 0.06 & 1.10 & 0.56 & 0.06 & 0.29 & $0.051 \mathrm{~ns}$ & 0.32 \\
\hline $\begin{array}{l}\text { The organisation of topics in tabs } \\
\text { helps to structure knowledge on }\end{array}$ & 0.55 & 1.07 & 0.05 & 0.45 & 1.12 & 0.06 & 0.95 & 0.78 & 0.08 & 0.50 & $0.00^{* * *}$ & 0.47 \\
\hline
\end{tabular}


sustainability

Reading Lists are appropriate to direct the learning of specific groups of users

D. The interactive facilities offered by the EDUCATE Portal

\begin{tabular}{|c|c|c|c|c|c|c|c|c|c|c|c|c|}
\hline $\begin{array}{l}\text { Asking questions online is useful } \\
\text { to support my teaching and } \\
\text { learning }\end{array}$ & 0.81 & 0.97 & 0.05 & 0.73 & 1.04 & 0.06 & 1.13 & 0.56 & 0.06 & 0.40 & $0.009^{* *}$ & 0.42 \\
\hline $\begin{array}{l}\text { Consultation of FAQs can } \\
\text { support my teaching and learning }\end{array}$ & 0.84 & 0.89 & 0.04 & 0.77 & 0.95 & 0.05 & 1.13 & 0.53 & 0.05 & 0.36 & $0.004^{\star *}$ & 0.41 \\
\hline $\begin{array}{l}\text { The online management of } \\
\text { design studios provides major } \\
\text { advantages }\end{array}$ & 0.84 & 0.91 & 0.05 & 0.79 & 0.97 & 0.05 & 1.03 & 0.64 & 0.07 & 0.24 & $0.067 \mathrm{~ns}$ & 0.26 \\
\hline $\begin{array}{l}\text { The possibility of receiving/giving } \\
\text { immediate online feedback is } \\
\text { useful }\end{array}$ & 0.93 & 1.00 & 0.05 & 0.82 & 1.07 & 0.06 & 1.29 & 0.60 & 0.06 & 0.47 & $0.00^{* * *}$ & 0.48 \\
\hline $\begin{array}{l}\text { The possibility of reviewing the } \\
\text { work of other students is a useful } \\
\text { feature }\end{array}$ & 0.86 & 1.03 & 0.05 & 0.82 & 1.08 & 0.06 & 1.01 & 0.83 & 0.09 & 0.19 & $0.207 \mathrm{~ns}$ & 0.19 \\
\hline
\end{tabular}

The results indicate that, across the whole sample of respondents, users largely agreed that elearning can support education for sustainability in design, help time management and foster autonomy in learning, encourage users to take responsibility of their education, and that online interactions can foster motivation and engagement. A statistically significant increase of practically relevant effect size was detected for agreement with the first two statements $(d=0.26$ and $d=0.29$, respectively) across the two stages of testing. This signals a raise in confidence in the opportunities offered by online learning, possibly facilitated also by increased familiarity with the improved functionalities of the Portal. The response of users to the layout, structure, and navigation through the EDUCATE Portal was moderately positive at the end of the Pilot Study, but significantly increased $(\Delta \mu=0.43, p=0.003, d=0.36)$ at the conclusion of the Field Test. At this stage, widely positive results were obtained also with regard to the Portal having supported the interest of users in sustainable design, a result significantly higher than the initial pilot $(\Delta \mu=0.40, p=0.005, d=0.37)$.

If considering the total sample of respondents, $80 \%$ (322 out of 405 ) declared their intention to continue using the EDUCATE Portal in their future education, a percentage that reached $90 \%$ (84 out of 93 users) after the second stage of testing, with a statistically significant and substantive increase in satisfaction $(\Delta \mu=0.41, p=0.005, d=0.41)$. Overall, EDUCATE Portal users were confident that its contents were relevant, and that delivering knowledge in layers of increasing depth, and with the support of targeted reading lists, enhanced their learning. A statistically significant increase in satisfaction of medium effect size was detected after the Field Test $(\Delta \mu=0.68, p=0.00, d=0.69)$ with respect to the usefulness of reading lists, also due to the full implementation of this feature. Finally, encouraging responses were obtained in terms of effectiveness of the interactive facilities offered by the Portal, such as asking questions online, consulting FAQs, offering opportunities for online management of design studios, and the possibility of providing interactive feedback and reviewing the 
work of other students. For most of these statements, the responses collected at the end of the Field Test provided a statistically significant increase in satisfaction of medium effect size.

Table 6 provides an analysis of the correlation - measured as strength of association (Spearman rho, $\rho)$ - between two 'control' questions and other selected statements of the survey. Spearman rho coefficients are provided for the total results of the survey and for each of the two stages of testing.

Table 6. Correlation analysis for selected statements of the EDUCATE Portal survey

\begin{tabular}{|c|c|c|c|c|c|c|}
\hline \multirow{2}{*}{$\begin{array}{l}\text { Strength of Association } \\
\text { between Statements } \\
\text { Spearman rho, } \rho^{\mathrm{ab}}\end{array}$} & \multicolumn{3}{|c|}{$\begin{array}{l}\text { E-learning can support education } \\
\text { for sustainability in design }\end{array}$} & \multicolumn{3}{|c|}{$\begin{array}{l}\text { I intend to use the EDUCATE Portal in } \\
\text { my future teaching and learning }\end{array}$} \\
\hline & $\begin{array}{l}\text { All Users } \\
(\mathrm{N}=405)\end{array}$ & $\begin{array}{l}\text { Pilot Study } \\
\quad(\mathrm{N}=312)\end{array}$ & $\begin{array}{l}\text { Field Test } \\
(\mathrm{N}=93)\end{array}$ & $\begin{array}{l}\text { All Users } \\
(\mathrm{N}=405)\end{array}$ & $\begin{array}{l}\text { Pilot Study } \\
\quad(\mathrm{N}=312)\end{array}$ & $\begin{array}{l}\text { Field Test } \\
\qquad(\mathrm{N}=93)\end{array}$ \\
\hline \multicolumn{7}{|c|}{ A. The use of e-learning tools in education } \\
\hline $\begin{array}{l}\text { E-learning can support } \\
\text { education for sustainability in } \\
\text { design }\end{array}$ & - & - & - & 0.93 & 0.91 & 0.95 \\
\hline $\begin{array}{l}\text { E-learning can support time } \\
\text { management and autonomy in } \\
\text { learning }\end{array}$ & 0.87 & 0.86 & 0.88 & 0.96 & 0.96 & 0.93 \\
\hline $\begin{array}{l}\text { E-learning can encourage } \\
\text { users to take responsibility of } \\
\text { their own learning }\end{array}$ & 0.81 & 0.82 & 0.72 & 0.91 & 0.95 & 0.75 \\
\hline $\begin{array}{l}\text { Online interactions among } \\
\text { users enhance motivation and } \\
\text { engagement }\end{array}$ & 0.93 & 0.93 & 0.95 & 0.99 & 0.99 & 0.99 \\
\hline \multicolumn{7}{|l|}{$B$. The use of the EDUCATE Portal } \\
\hline $\begin{array}{l}\text { The layout, structure and } \\
\text { navigation of the EDUCATE } \\
\text { Portal are intuitive }\end{array}$ & 0.72 & 0.74 & 0.63 & 0.78 & 0.80 & 0.65 \\
\hline $\begin{array}{l}\text { The EDUCATE Portal has } \\
\text { supported my interest in } \\
\text { sustainable design }\end{array}$ & 0.75 & 0.76 & 0.68 & 0.87 & 0.89 & 0.72 \\
\hline $\begin{array}{l}\text { The EDUCATE Portal has } \\
\text { helped my teaching and } \\
\text { learning experience }\end{array}$ & 0.69 & 0.71 & 0.54 & 0.79 & 0.83 & 0.55 \\
\hline $\begin{array}{l}\text { I intend to use the EDUCATE } \\
\text { Portal in my future teaching and } \\
\text { learning }\end{array}$ & 0.93 & 0.91 & 0.95 & - & - & - \\
\hline \multicolumn{7}{|l|}{ C. The EDUCATE Knowledge Base } \\
\hline $\begin{array}{l}\text { The contents of the EDUCATE } \\
\text { Knowledge Base are relevant } \\
\text { and useful }\end{array}$ & 0.81 & 0.83 & 0.67 & 0.90 & 0.93 & 0.70 \\
\hline $\begin{array}{l}\text { The organisation of topics in } \\
\text { tabs helps to structure } \\
\text { knowledge on sustainability }\end{array}$ & 0.69 & 0.70 & 0.61 & 0.80 & 0.82 & 0.64 \\
\hline $\begin{array}{l}\text { Reading Lists are appropriate } \\
\text { to direct the learning of specific } \\
\text { groups of users }\end{array}$ & 0.78 & 0.74 & 0.95 & 0.88 & 0.85 & 0.90 \\
\hline \multicolumn{7}{|c|}{ D. The interactive facilities offered by the EDUCATE Portal } \\
\hline $\begin{array}{l}\text { Asking questions online is } \\
\text { useful to support my teaching } \\
\text { and learning }\end{array}$ & 0.75 & 0.77 & 0.60 & 0.84 & 0.87 & 0.63 \\
\hline $\begin{array}{l}\text { Consultation of FAQs can } \\
\text { support my teaching and } \\
\text { learning }\end{array}$ & 0.74 & 0.75 & 0.64 & 0.81 & 0.84 & 0.67 \\
\hline $\begin{array}{l}\text { The online management of } \\
\text { design studios provides major }\end{array}$ & 0.75 & 0.77 & 0.60 & 0.83 & 0.86 & 0.63 \\
\hline
\end{tabular}


advantages

The possibility of receiving/giving immediate online feedback is useful

The possibility of reviewing the work of other students is a useful feature

${ }^{a} \rho \geq 0.20=$ small; $\rho \geq 0.50=$ moderate; $\rho \geq 0.80=$ strong

b $\rho$-coefficients in bold italic indicate a strong correlation (all reported associations are significant at the .05 level)

The correlation analysis detected a strong positive association between the view that e-learning can support education for sustainability in design and the motivation and engagement enhanced by online interactions. Similar results were obtained for the correlation between the intention to continue using the Portal, and the opportunities afforded by interfacing with other user groups. The willingness to keep utilising the Portal was also strongly positively correlated with the potential offered by elearning to support time management and autonomy in learning, and the promotion of interest in sustainable design. In terms of the EDUCATE Knowledge Base, the relevance of its contents and the availability of reading lists were among the reasons for users to continue accessing it. This was evident particularly at the end of the Field Test, where very strong positive correlations were detected between the appropriateness of reading lists, the view that e-learning can support education for sustainability in design, and the intention to keep using the Portal. Finally, among the interactive facilities offered, the possibility of receiving (and providing) immediate online feedback was considered a key feature and the main motivation to keep accessing the Portal. Also in this case, the full implementation of this interactive feature (Field Test) resulted in higher correlation coefficients.

\section{EDUCATE on SITE Evaluation}

In the Trial Run, five participants directly used both the EDUCATE on SITE App and the online version of the EDUCATE Portal via the mobile device browser, five accessed the Portal solely by the device browser, and one used only the EDUCATE on SITE App. The results for selected statements of the Post-questionnaire survey are summarised in Table 7, although caution should be used in all inferences due to the very small and self-selected sample size.

Table 7. Descriptive statistics, null hypothesis significance testing (NHST, one-sided), and effect size for selected statements of the EDUCATE on SITE Post-questionnaire

\begin{tabular}{|c|c|c|c|c|c|c|c|c|c|c|c|c|}
\hline \multirow[t]{2}{*}{ Proposed Statement } & \multicolumn{3}{|c|}{$\begin{array}{l}\text { All Users } \\
(\mathrm{N}=11)\end{array}$} & \multicolumn{3}{|c|}{$\begin{array}{c}\text { App \& Browser } \\
(\mathrm{N}=5)\end{array}$} & \multicolumn{3}{|c|}{$\begin{array}{l}\text { Browser only } \\
\qquad(\mathrm{N}=5)\end{array}$} & \multicolumn{2}{|c|}{\begin{tabular}{|c|} 
NHST \\
(Browser vs. \\
App\&Browser)
\end{tabular}} & \multirow{2}{*}{$\begin{array}{c}\text { Effect } \\
\text { Size } \\
d^{c}\end{array}$} \\
\hline & $\mu^{a}$ & $S D^{a}$ & $S^{a}$ & $\mu^{\mathrm{a}}$ & $\mathrm{SD}^{\mathrm{a}}$ & $S E^{a}$ & $\mu^{\mathrm{a}}$ & $\mathrm{SD}^{\mathrm{a}}$ & $\mathrm{SE}^{\mathrm{a}}$ & $\Delta \mu$ & $p^{\mathrm{b}}$ & \\
\hline $\begin{array}{l}\text { Mobile ac } \\
\text { Portal is } u\end{array}$ & 1.82 & 0.40 & 0.12 & 1.80 & 0.45 & 0.13 & 1.80 & 0.45 & 0.13 & 0.00 & $0.559 \mathrm{~ns}$ & 0.00 \\
\hline $\begin{array}{l}\text { Mobile access to the EDUCATE } \\
\text { Portal is useful to access the } \\
\text { Knowledge Base }\end{array}$ & 1.40 & 0.52 & 0.16 & 1.20 & 0.45 & 0.13 & 1.75 & 0.50 & 0.15 & 0.55 & $0.078 \mathrm{~ns}$ & 1.16 \\
\hline $\begin{array}{l}\text { Mobile access to the EDUCATE } \\
\text { Portal is useful to connect with } \\
\text { the map service }\end{array}$ & 0.40 & 1.07 & 0.32 & 0.40 & 1.34 & 0.40 & 0.33 & 1.15 & 0.35 & -0.07 & $0.628 \mathrm{~ns}$ & -0.05 \\
\hline
\end{tabular}


Mobile access to the EDUCATE Portal is useful and should be implemented

I prefer the app on a mobile phone over micro browser access to the Portal

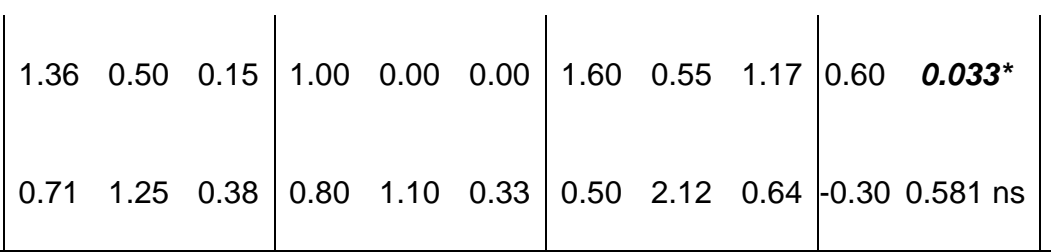

${ }^{a} \mu=$ mean; $\mathrm{SD}=$ standard deviation; $\mathrm{SE}=$ standard error

$\mathrm{b}{ }^{* * *} p<0.001 ;{ }^{* *} p<0.01 ;{ }^{*} p<0.05 ; \mathrm{ns}=$ not significant ( $p$-values in bold italic are significant at the .05 level)

${ }^{c} d \geq 0.20=$ small; $d \geq 0.50=$ medium; $d \geq 0.80=$ large ( $d$-indexes in bold italic are significant at the .05 level)

The table provides descriptive statistics for the results of the Post-questionnaire, separately considering the responses of all participants $(\mathrm{N}=11)$ and of the two prevalent user types (App \& Browser, $\mathrm{N}=5$; and Browser only, $\mathrm{N}=5$ ). Table 7 also gives an analysis of the variation in mean response $(\Delta \mu)$ between the two main types of user, the statistical significance of the differences ( $p$ value), and their effect size (d-index). The results suggest that all responses were generally positive $(0.33 \leq \mu \leq 1.82)$. All students found it useful to connect to the Portal via a mobile device and thought that access to its features on-the-move should be fully implemented. A statistically significant difference between user types could be detected for this last statement, whereas users having accessed the Portal only via the browser expressed a higher agreement $(\Delta \mu=0.60 ; p=0.033 ; d=1.55$, large effect size). This result may be linked to a higher familiarity with the web layout of the Portal compared to the App. Interestingly, the most attractive feature consisted in the possibility of asking questions online, regardless of whether this functionality was accessed via the App or the mobile browser.

Table 8 provides descriptive statistics for further statements of the Post-questionnaire addressed specifically to the students that used both the App and the browser $(\mathrm{N}=5)$, and to those that uniquely accessed the Portal via its online version $(\mathrm{N}=5)$.

Table 8. Descriptive statistics for selected statements of the EDUCATE on SITE Post-questionnaire

\begin{tabular}{|c|c|c|c|}
\hline Proposed Statement & $\mu^{\mathrm{a}}$ & $\mathrm{SD}^{\mathrm{a}}$ & $\mathrm{SE}^{\mathrm{a}}$ \\
\hline \multicolumn{4}{|l|}{ App and Browser access to the EDUCATE Portal Users $(\mathrm{N}=5)$} \\
\hline Navigation and use of the app was intuitive & 0.60 & 0.89 & 0.27 \\
\hline The app made good use of the device screen & 0.80 & 1.64 & 0.50 \\
\hline The functionality of the app was sufficient & 0.00 & 1.41 & 0.43 \\
\hline The app was useful and I would use it in the future & 1.00 & 0.00 & 0.00 \\
\hline \multicolumn{4}{|l|}{ Browser access only to the EDUCATE Portal Users $(N=5)$} \\
\hline Navigation and use of the mobile version of the EDUCATE Portal was intuitive & 1.20 & 0.45 & 0.13 \\
\hline The mobile version of the EDUCATE Portal made good use of the device screen & 0.80 & 1.10 & 0.33 \\
\hline The functionality of the mobile version of the EDUCATE Portal was sufficient & 1.00 & 0.00 & 0.00 \\
\hline The mobile version of the Portal was useful and I would use it in the future & 1.40 & 0.55 & 0.17 \\
\hline
\end{tabular}

${ }_{\mathrm{a}} \mu=$ mean; $\mathrm{SD}=$ standard deviation; $\mathrm{SE}=$ standard error

Also these results were mostly positive, with the only exception of the statement on the functionality of the App, for which users maintained a neutral position. However, it must be considered that in the Trial Run only the facilities related to browsing the Knowledge Base and asking a question had been activated. The users who directly trialled the EDUCATE on SITE App were sufficiently satisfied about the intuitiveness of its use, and recognised its ability to adjust content to the screen and hide redundant navigation elements to optimise the use of the display. Similarly positive results were obtained for users who only accessed the Portal via the mobile device browser. In this case, users 
were also likely supported by a higher acquaintance with the Portal's layout and contents, leading to a more explicit satisfaction with its ease of use and operability.

\section{Discussion}

Student-centred and Deep Learning

The pervasive influence of the agenda of sustainability offers a framework in which the ability to engage creatively and critically with the interconnectedness of social, economic, and environmental issues can help stimulate curriculum reform, placing a premium upon student-centred and deep learning propensities, and grappling with the intrinsic "range and interconnectedness" of the subject (Warburton, 2003). Student-centred learning has emerged as a dominant goal to enable students to work within the higher cognitive levels of application, analysis, synthesis, and evaluation (Baeten et al., 2010), by giving "greater autonomy and control over the choice of subject matter, learning methods and pace of study" (Gibbs, 1992), and "providing some flexibility in terms of the place, pace, time and content of student learning" (SLICE, 2002). These definitions imply a requirement for students to take on responsibility and active control over the processes of planning and evaluating their own progress, without relying uniquely on lecturers to spoon feed them (Dowdle, 2006). This brings significant challenges as to the extent to which educators are able to facilitate deep as opposed to surface (i.e., dictated by a concern to memorise facts without reflection) or strategic (i.e., prioritising the production of work felt to best correspond with the tutor's agenda) learning (Maclellan, 2008).

The outcomes of the study presented here suggest that ICT-enhanced pedagogies can bring advantages beyond the simple, yet efficient, maintenance of up-to-date course material, also guaranteeing flexible time and pace of learning, integration of different media, and opportunities for live collaboration and feedback. Indeed, the improvements obtained by students following the development of the EDUCATE Portal, and their density distribution progressively peaking towards higher values (Tables 2-3, and Figure 1), present encouraging trends, although these findings need to be considered with caution due to the relative short-term of the analysis performed (only three academic years) and the potential presence of other confounding factors (e.g., characteristics of the students' cohorts). However, the effect size of the improvements detected ( $d=0.26,0.32$ and 0.54$)$ are in line with those documented in the literature (Kulik and Kulik, 1991) and support the inference that the learning tools implemented may have contributed to raise students' academic performance.

This is confirmed by the feedback obtained on the implementation of the EDUCATE Portal in the curriculum (Table 4), suggesting that e-learning can offer an opportunity to contextualise and consolidate, at the users' pace, knowledge acquired from lectures, textbooks or other sources. However, it is important that the layout of interactive tools is intuitive and engaging so as to facilitate access for learners at various stages of education, and guarantee a large user-base that can increase sharing of knowledge, peer-learning, and cooperation. Certainly, online pedagogical tools cannot be a complete substitution to face-to-face tutoring, but if coupled with experiential learning and supported by a mixture of ex-cathedra delivery, self-study, seminars, and workshops, they can reinforce studentcentred and deep learning, particularly in the domain of sustainable design (Diamond and Irwin, 2013). It follows that online learning should be integrated within blended approaches (Bacelar-Nicolau et al., 
2009), where web-based tools are used not only on the front-end of the classroom, but also before and after the lecture, triggering discussion on concepts, and fostering the active participation of students to the construction of contextual knowledge situated "out there" (Alvarez and Rogers, 2006).

\section{Contextual Knowledge and Technology}

Boyle and Ravenscroft (2012) presented an argument for assuming context as the core unit of deep learning, to "encourage the creative study of a learning problem or opportunity" exploiting "the affordances of the technology in order to develop contexts that empower learners to achieve educational goals". Boyle (2002) also stated that context is the "natural base concept for the learning technologist", suggesting that "the central challenge for educational designers is to create contexts that promote effective learning". "Authentic" learning requires that contexts reflect the real world where knowledge and skills can be deployed (Herrington and Oliver, 2000). These views are significant to the transition from an educational process enhanced by the traditional classroom (or design studio) scenario to activities in the field supported by mobile learning, advocating the engagement of students as active, creative, and reactive agents of the learning process "anytime and anywhere" (Mottiwalla, 2007). These constructivist approaches are in contrast to behaviourist methods where students go through rigid, pre-defined steps to achieve correct learning (Perkins, 2006).

In this direction, it is interesting that all participants to the EDUCATE on SITE study who trialled the App declared their intention to use it in the future (Table 8). Also, the view that an App can foster motivation and engagement with learning was fairly shared by all. This was mainly due to its intuitive and concise layout, its ease of navigation, and an optimised use of the screen that made it suitable to access knowledge and interact with others while on-the-move (for example, when on a site visit).

Situated learning should, however, be considered as more than just the contextualisation of a pedagogy based on learning by doing (Cobb and Bowers, 1999). Lave and Wenger's (1991) concept of situatedness, in fact, is a model of learning in a "community of practice" that involves users being fully participating in generating meaning. Students should learn contents through activities instead of acquiring information in discrete packages organized by instructors - one of the very reasons why volunteers on the EDUCATE on SITE evaluation where assigned group tasks (Langer, 2009).

In contrast to traditional cognitive theory - where learners memorise, store, and reproduce contents on demand within formal education contexts - the situated approach perceives learning to be a socially relational process, placing attention on knowledge production rather than passive classroom transmission. Transferring the education into the everyday life of students, in situated learning thinking itself is contextualised and viewed from a perspective of ecological psychology, emphasising perception rather than memory as the means by which learning takes place (Young, 1993; Gibson, 1986). Situated learning can exploit participative and interactive methods to help learning information, and motivating individuals to acquire and practice skills in a social context (Anderson et al., 1996).

\section{Motivation, Engagement and Interactive Learning}

In any pedagogical process, ensuring that learning is made personally meaningful can help to tap into motivation and gain an understanding of student agency, without which "young people are unlikely 
to pose [the] significant questions" that effective education demands (Darder et al., 2003). Given the scale of the sustainability challenge, it may be contended that a robust engagement with its agenda is contingent upon the degree of formal and informal incentive felt by educators and learners. Motivation is the major factor that promotes students to learn, triggering interest in their tasks, making them absorb the teaching more readily and change their values and behaviours (Skinner and Belmont, 1993). It has been argued that whilst students may be, and often appear, de-motivated, they are not intrinsically un-motivated. The key challenge for educators is thus to enable de-motivated learners to engage and actively participate to the learning process (Biggs and Tang, 2007). Yet, teachers need to be wary, since what motivates some students may alienate others (Hidi and Harackiewicz, 2000).

In this direction, the results of this study support the hypothesis that students' motivation could be enhanced by e-learning and m-learning, ultimately leading to improvement in academic results and, possibly, changes of attitudes (Shephard, 2008; Sutton and Gyuris, 2015). Analysis of the Portal survey further contributes to interpret users' responses to the pedagogy, whereas the engagement enhanced by online interactions, and the opportunity to promote autonomy in learning, were strongly correlated with the view that e-learning can reinforce education for sustainability in design and with the intention to continue using the Portal. To note that sharing of knowledge, peer-learning, feedback (a strong source of extrinsic motivation, particularly effective if timely provided; Shute, 2007), and interactive cooperation were among the strengths of the Portal in students' evaluations.

Moore (1989) illustrated three types of interaction that can take place with the use of ICTs in education: learner-content, learner-instructor and learner-learner. This study has offered the opportunity to practice all of these. In terms of the first two, the role of the instructor in the EDUCATE Portal and EDUCATE on SITE studies was that of a facilitator - "from sage on the stage to guide on the side" (King, 1993) - so as to: engage learners with the assimilation of knowledge (learner-content); guide students through their learning (e.g., via reading lists); but also provide structured scaffolding in project development (learner-instructor). Reflection-in-action (Schon, 1984) was promoted by inviting students to look back to previous work and project forward to imminent tasks, entailing as much anticipative thought and analysis as retrospective review (Grierson, 2004). This process of documentation and critical reflection was enhanced by recording students' progress via the Portal and by exchanges with other users (learner-learner) (Betrabet-Gulwadi, 2009).

In essence, solutions to promote an understanding of the complex, and conceptually composite, nature of motivation and engagement within education for sustainability seem bound to confront traditional modes of teaching and learning to allow knowledge acquisition and application to be more closely synchronised. Contrary to the traditional mainstay of academic pedagogies - the teacher as the central figure that delivers education - students should build a knowledge network relating the principles acquired to real experience. As illustrated by this study, a responsive and interactive - rather than merely transmissive - approach to education, when supported by tailored e-learning and $\mathrm{m}$ learning pedagogical methods and tools, holds the potential to engage in student-centred and deep learning, stimulating a flexible and immersive exploration of situated knowledge. In addition, social learning tools can afford interactions among agents of the learning process (learners and instructors), virtually connecting individuals within an online community of practice (Halverson, 2009). 


\section{Conclusion, Limitations and Further Research}

The agenda of sustainability is strongly impacting upon curricula of higher education, requiring a shift in teaching and learning practices. Interactive and situated pedagogical methods and tools, such as the EDUCATE Portal and the EDUCATE on SITE App, have the potential to stimulate curriculum reform towards educational models that enrich the learning experience with a flexible and immersive acquisition and application of knowledge. To support education for sustainability, pedagogical processes need to evolve beyond simply a review of their contents. At times, this should involve engaging with knowledge and other individuals (instructors and peers) in traditional lectures or studio activities and, at times, interacting in e-learning or m-learning environments. This should force disciplines of the built environment to confront their traditional compartmentalisation of knowledge, and - by enabling teaching and learning to take place outside the physical boundaries of the academic setting - stimulate critical reflection, motivation, student-centred and deep learning, participatory development of critical analysis, synthesis, and creative problem-solving skills, all paramount to provide the multi/inter/trans-disciplinary responses necessary to tackle contemporary challenges.

In this direction, this study adds empirical evidence to the following findings:

- Interactive and situated learning can provide a relevant contribution to improve students' academic results in sustainable design;

- ICTs-enhanced education can foster time management, independence, and responsibility in learning, offering opportunities for interaction between users;

- Online learning is valued by students primarily as a way to enhance communication and feedback, other than to access knowledge and course material at the learners' pace;

- The layout and interface of e-learning and m-learning tools need to be intuitive and engaging to appeal users and expand networking opportunities;

- Online learning cannot represent a total substitute to face-to-face tuition but needs to be blended with experiential educational methods;

- Students and educators require training and time to acquire familiarity with electronic media for their confident integration in higher education.

In embracing these findings, teachers and curriculum designers are tasked to prompt a departure from institutionally-framed educational models that disconnect the contexts in which skills are attained and practiced, and reinforce participatory engagement with the learning process. If properly integrated in the education, and supported by adequate guidance for both teachers and learners, interactive and situated learning can enhance the shift from pure instructor-centred, classroom-based, pedagogies towards learner-centred contextualised educational settings that can provide versatility of access to knowledge independently of time and place, and offer methods of communication that can enhance the educational experience. In so doing, the design of pedagogical practices needs to be based on the requirement to set engaging and real tasks for the learners, making appropriate and effective use of varied media, yet leaving to students a level of control of their own learning (even if with suitable scaffolding support) while providing constructive and timely feedback on progress. Technology is an 
important influence in students' lives, but it is one among many, and educators are charged with the responsibility to help students navigate successfully through its benefits and limitations.

In contextualising the findings of this study, it must be considered that the results were constrained by an exclusive focus on the development and testing of interactive and situated pedagogical tools aiming to promote students' motivation and engagement with the agenda of sustainability in the design of the built environment. The tools trialled were mostly at their prototypical stage, with relatively limited functionality, and their testing was centred solely on the analysis of whether learners acquire knowledge in the short-term to be swiftly practiced in design coursework. In addition, demographic information of participants (e.g., age, gender, etc.) was not consistently recorded and was thus excluded from the analysis. Future research will need to consider collecting such data for a more thorough correlation of responses. Further testing should also include a larger user-base whose learning outcomes should be compared against a control group taught by traditional pedagogical methods. Finally, the analysis should also look into the long-term effects of integrating elearning and $\mathrm{m}$-learning in higher education pedagogies.

\section{Acknowledgments}

EDUCATE was funded by the European Commission under the Intelligent Energy Europe Programme (Contract $n$. IEE/08/635/SI2.528419). EDUCATE on SITE was funded by HEA/JISC under the Open Educational Resources Case Studies Series (Reference n. CS 15). The authors wish to acknowledge the contribution of Dr Neil Madden and Julian Zappala to the design and development of the EDUCATE Portal, and of Andrew Gibson and Rebecca Smith for their research on education for sustainability. The contribution of all EDUCATE partners, Portal users, and EDUCATE on SITE study participants is also thankfully recognized.

\section{References}

Altomonte, S., Rutherford, P., and Wilson, R. (2014), "Mapping the way forward: Education for sustainability in architecture and urban design", Corporate Social Responsibility and Environmental Management, Vol.21 No.3, pp.143-154.

Altomonte, S., Feisst, M., and Logan, B. (2012). EDUCATE on SITE: User acceptance of mobile web applications in architectural education on sustainable environmental design, HEA/JISC Open Educational Resources, York.

Alvarez A., and Rogers, J. (2006), "Going "out there": learning about sustainability in place", International Journal of Sustainability in Higher Education, Vol.7 No.2, pp.176-188.

Anderson, J.R., Reder, L.M., and Simon, H.A. (1996), "Situated learning and education", Educational Researcher, Vol.25 No.4, pp.5-11.

Bacelar-Nicolau, P., Caeiro, S., Martinho, A.P., Azeiteiro, U.M., and Amador, F. (2009), "E-learning for the environment", International Journal of Sustainability in Higher Education, Vol.10 No.4, pp.354-367. Baeten, M., Kyndt, E., Struyven, K., and Dochy, F. (2010), "Using student-centred learning environments to stimulate deep approaches to learning: factors encouraging or discouraging their effectiveness", Educational Research Review, Vol.5 No.3, pp.243-260. 
Beck, J.C., and Wade, M. (2006), The kids are alright: How the gamer generation is changing the workplace, Boston, Harvard Business School Press.

Bekebrede, G., Warmelink, H.J.G., and Mayer, I.S. (2011), "Reviewing the need for gaming in education to accommodate the net generation", Computers \& Education, Vol.57 No.2, pp.1521-1529.

Betrabet-Gulwadi, G. (2009), "Using reflective journals in a sustainable design studio", International Journal of Sustainability in Higher Education, Vol.10 No.2, pp.96-106.

Biggs, J., and Tang, C. (2007), Teaching for quality education at University: what the student does, Open University Press, Maidenhead.

Boyle, T., and Ravenscroft, A. (2012), "Context and deep learning design", Computers \& Education, Vol.59 No.4, pp.1224-1233.

Boyle, T. (2002), "Towards a theoretical base for educational multimedia design", Journal of Interactive Media in Education, Vol.2 No.2, pp.1-16.

Brown, S.A. (2014), "Conceptualizing digital literacies and digital ethics for sustainability education", International Journal of Sustainability in Higher Education, Vol.15 No.3 pp.280-290.

Cobb, P., and Bowers, J. (1999), "Cognitive and situated learning perspectives in theory and practice", Educational Researcher, Vol.28 No.2, pp.4-15.

Cohen, J. (1994), "The earth is round ( $p<.05)$ ", American Psychologist, Vol.49 No.12, pp.997-1003.

Cohen, J. (1992), “A power primer”, Psychological Bulletin, Vol.112 No.1, pp.155-159.

Darder, A., Baltodano, M., and Torres, R. (2003), The critical pedagogy, Routledge, London.

Diamond, S., and Irwin, B. (2013), "Using e-learning for student sustainability literacy: framework and review", International Journal of Sustainability in Higher Education, Vol.14 No.4, pp.338-348.

Dowdle, D.L. (2006), "Engaging learners - The development of effective e-learning applications for students of the built environment", Architectural Engineering and Design Management, Vol.2 No.1, pp.31-48.

EDUCATE (2012a), "EDUCATE Results summary", available at: http://www.educatesustainability.eu/results-summary (accessed 05 December 2014).

EDUCATE (2012b), "EDUCATE Portal development and testing", available at http://www.educatesustainability.eu/portal-development (accessed 23 February 2015).

Ellis, P.D. (2010), The essential guide to effect sizes, University Press, Cambridge.

Ferguson, C.J. (2009), "An effect size primer: A guide for clinicians and researchers", Professional Psychology: Research and Practice, Vol.40 No.5, pp.532-538.

Field, A., and Hole, G. (2003), How to design and report experiments, Sage, London.

Furió, D., González-Gancedo, S., Juana, M., Seguí, I., and Rando, N. (2013), "Evaluation of learning outcomes using an educational iPhone game vs. traditional game", Computers \& Education, Vol.64, pp.1-23.

Gelernter, M. (1988), "Reconciling lectures and studio", Journal of Architectural Education, Vol.41 No.2, pp.46-52.

Gibbs, G. (1992), Improving the quality of student learning, Technical \& Educational Services, Plymouth.

Gibson, J.J. (1986), The ecological approach to visual perception, Lawrence Erlbaum, Hillsdale. 
Gikas, J., and Grant, M.M. (2013), "Mobile computing devices in higher education: student perspectives on learning with cellphones, smartphones and social media", Internet and Higher Education, Vol.19, pp.18-26.

Grierson, H. (2004), "The internet as a tool for communication in design projects", CEBE Transactions, Vol.1 No.2, pp.77-90.

Halverson, A.C. (2009), Rethinking education in the age of technology, Teachers College Press, New York.

Herrington, J., and Oliver, R. (2000), "An instructional design framework for authentic learning environments", Educational Technology Research and Development, Vol.48 No.3, pp.23-48.

Hidi, S., and Harackiewicz, J.M. (2000), "Motivating the academically unmotivated. A critical issue for the 21st century", Review of Educational Research, Vol.70 No.2, pp.157-179.

lulo, L.D., Gorby, C., Poerschke, U., Kalisperis, L.N., and Woollen, M. (2013), "Environmentally conscious design - educating future architects", International Journal of Sustainability in Higher Education, Vol.14 No.4, pp.434-448.

Jones, P., Selby, D., and Sterling, S. (2010), "More than the sum of their parts? Interdisciplinarity and sustainability", in Jones, P., Selby, D., and Sterling, S. (Eds.), Sustainability education: Perspectives and practice across higher education, Earthscan, London, pp.17-38.

Kebritchi, M., and Hirumi, A. (2008), "Examining the pedagogical foundations of modern educational computer games", Computers \& Education, Vol.51 No.4, pp.1729-1743.

King, A. (1993), "From sage on the stage to guide on the side", College Teaching, Vol.41 No.1, pp.3035.

Kolb, D.A. (1984), Experiential Learning: Experience as the source of learning and development, New Jersey, Prentice-Hall.

Kulik, C-L.C., and Kulik, J.A. (1991), "Effectiveness of computer-based instruction: an updated analysis", Computers in Human Behaviour, Vol.7 Nos.1-2, pp.75-94.

Langer, P. (2009), "Situated learning: What ever happened to educational psychology?", Educational Psychology Review, Vol.21 No.2, pp.181-192.

Lave, G., and Wenger, E. (1991), Situated learning: Legitimate peripheral participation, University Press, Cambridge.

Leal Filho, W., Manolas, E., and Pace, P. (2015), "The future we want: key issues on sustainable development in higher education after Rio and the UN decade of education for sustainable development", International Journal of Sustainability in Higher Education, Vol.16 No.1.

Leal Filho, W. (2000), "Dealing with misconceptions on the concept of sustainability", International Journal of Sustainability in Higher Education, Vol.1 No.1, pp.9-19.

Littlejohn, A., Falconer, I., and Mcgill, L. (2008), "Characterising effective eLearning resources", Computers \& Education, Vol.50 No.3, pp.757-771.

Maclellan, E. (2008), "The significance of motivation in student-centred learning: a reflective case study", Teaching in Higher Education, Vol.13 No.4, pp.411-421.

Marton, F., and Säljö, R. (1976), "On qualitative differences in learning 2: Outcome as a function of the learner's conception of the task", British Journal of Educational Psychology, Vol.46 No.2, pp.115-27. 
Moore, J.L., Dickson-Deane, C., and Galyen, K. (2011), "e-Learning, online learning, and distance learning environments: are they the same?", Internet and Higher Education, Vol.14, pp.129-135.

Moore, M. G. (1989), "Editorial: Three types of interaction”, American Journal of Distance Education, Vol.3 No.2, pp.1-7.

Mottiwalla, L.F. (2007), "Mobile learning: a framework and evaluation", Computers \& Education, Vol.49 No.3, pp.581-596.

Perkins, D. (2006), "Constructivism and troublesome knowledge", in Meyer, J.H.F., and Land, R. (Eds.), Overcoming barriers to student understanding, threshold concepts and troublesome knowledge, Routledge, Abingdon, pp.33-47.

Prensky, M. (2001), Digital game-based learning, New York, McGraw-Hill.

Schiavon, S., and Altomonte, S. (2014). "Influence of factors unrelated to environmental quality on occupant satisfaction in LEED and non-LEED certified buildings". Building and Environment, Vol. 77, pp. 148-159.

Schon, D.A. (1984), "The architectural studio as an exemplar of education for reflection-in-action", Journal of Architectural Education, Vol.38 No.1, pp.2-9.

Shephard, K., (2008), "Higher education for sustainability: seeking affective learning outcomes", International Journal of Sustainability in Higher Education, Vol.9 No.1, pp.87-98.

Shute, V.J. (2007), Focus on formative feedback, Princeton, New Jersey.

Skinner, E.A., and Belmont, M.J. (1993), "Motivation in the classroom: reciprocal effects of teacher behavior and student engagement across the school year", Journal of Educational Psychology, Vol.85 No.4, pp.571-581.

SLICE (2002), Handbook on student-centred learning in construction education, University of Plymouth, Plymouth.

Sutton, S., and Gyuris, E. (2015), "Optimizing the Environmental Attitudes Inventory: establishing a baseline of change in students' attitudes", International Journal of Sustainability in Higher Education, Vol.16 No.1.

Tapscott, D. (1998), Growing up digital. The rise of the net generation, New York, McGraw-Hill.

Thompson, P. (2013), "The digital natives as learners: Technology use patterns and approaches to learning", Computers \& Education, Vol.65, pp.12-33

Traxler, J. (2010), "Distance education and mobile learning: Catching up, taking stock", Distance Education, Vol.31 No.2, pp.129-138.

Warburton, K. (2003), "Deep learning and education for sustainability", International Journal of Sustainability in Higher Education, Vol.4 No.1, pp.44-56.

Wright, J. (2003), "Introducing sustainability into the architecture curriculum in the United States", International Journal of Sustainability in Higher Education, Vol.4 No.2, pp.100-105.

Young, M.F. (1993), "Instructional design for situated learning", Educational Technology Research and Development, Vol.41 No.1, pp.43-58. 


\section{About the authors}

Dr Sergio Altomonte is Associate Professor at the Department of Architecture and Built Environment, University of Nottingham, where he teaches and researches in the field of architecture and sustainability. He is currently Department Director of Teaching and Learning and member of the University Quality and Standards Committee. A Fellow of the UK Higher Education Academy, he holds a MArch in Architecture and a PhD in Environmental Design from the University La Sapienza (Rome, Italy) and a Master in Sustainable Architecture from the EPFL (Lausanne, Switzerland). He has held academic positions in Italy and Australia, and has been a visiting scholar at the University of California Berkeley (USA) and the Royal Danish Academy (Copenhagen, Denmark). Among several other research initiatives, he was the Coordinator of the European project EDUCATE.

Dr Brian Logan is Associate Professor at the School of Computer Science, University of Nottingham. Prior to coming to Nottingham, he was a lecturer in Artificial Intelligence in the School of Computer Science at the University of Birmingham, and also worked at the University of Cambridge Martin Centre for Architectural and Urban Studies on architectural CAD systems and the Computer Laboratory on computational models of belief revision, and at the Department of Artificial Intelligence at the University of Edinburgh on design support systems. His research interests lie in the area of agent systems, and span the specification, design, and implementation of agents, including agent architectures, agent programming languages and logics and theories for agent-based systems. $\mathrm{He}$ is also interested in applications of agents, particularly in virtual environments and in simulation.

Dr Markus Feisst received his PhD at the University Louis Pasteur (Strasbourg, France) in 2006 and his MSc in Communication and Media Engineering at the University of Applied Sciences Offenburg (Germany) in 2000. After a period spent as a research staff in the Mobile Communication and Waves Lab at the University of Applied Sciences Offenburg, between 2009 and 2012 he held the position of Research Assistant and Software Engineer at the School of Computer Science, University of Nottingham. He is currently Team Leader Product Development at Meyle+Müller GmbH+Co. KG.

Dr Peter Rutherford is Associate Professor at the Department of Architecture and Built Environment, University of Nottingham. He obtained from the University of Strathclyde his BSc in Architecture in 1993, his MSc in Computer Aided Design in 1994, and his PhD on Architectural and Psychoacoustics in 1997. After his doctoral studies, he worked as an applications engineer for a major acoustics company as well as spending three years as a postdoctoral research fellow in the Medical School at the University of Leeds. Many of his teaching techniques were gleamed from the interdisciplinary and applied nature of medical training. With Dr Robin Wilson, he has published on creativity within an integrated environmental design curriculum, their efforts rewarded in 2007 through the receipt of the University of Nottingham's Lord Dearing Award for excellence in teaching.

Dr Robin Wilson is currently the Head of the Department of Architecture and Built Environment at the University of Nottingham. He holds a BSc in Building and a PhD in Architectural Acoustics from Heriot-Watt University. After having spent periods of research as a post-doctoral research associate at Heriot-Watt University and the University of Hull, he joined the University of Nottingham in 1995 where he engaged with the teaching of environmental design to architecture and engineering students. $\mathrm{He}$ was responsible for setting up a master course in renewable energy and architecture, and later served 
as the course director to an innovative undergraduate master programme in architecture and environmental design accredited by both the architectural and engineering professional bodies in UK. 